\title{
A Lightning Strike and a Poisoning
}

\author{
Aeger Gratulanter
}

On Midsummer Day this year I was pottering around Lancaster Market, aiming for the plant stall. It was hot, humid and overcast - headache weather! There was a second when everything seemed to fall silent and still. Then a throng of mystified customers started pouring out of the suddenly-dark shops. There'd been no crashing thunder, no heavy rain but there had been a lightning strike. All lights, tills, card machines, coffee makers, computers, the lot, had stopped. The Market traders couldn't believe their luck!

The misfortune to hit businesses, offices and homes that day a few weeks ago reminded me, painfully, of another day in Lancaster when unstoppable natural forces collided with my utter idiocy, making for one of those visits to $A \& E$ that I've buried deep in my psyche.

I can't remember the exact year - not more than four years ago - but no matter. The weather was exactly the same and I was ironing, which was a bit mad in that heat. That last small detail is important.

Events went like this: the sheets were too dry to iron. My steam iron wouldn't steam. I needed a spray, but didn't have one. I took a bottle of mineral water and a spray bottle of "Shout" cleaning fluid and swapped the contents. While my back was turned, my husband - henceforth to be known as "M" - came in and took a swing of what he thought was mineral water. I screamed. That's how the poisoning part of this story happened.

Terror, shouting and a lot of running about pointlessly followed. $M$ was convinced that he would die in agony at any moment, and I too was convinced of that, although I didn't admit it. We ran to the car. I skidded back to collect the "Shout" bottle, and we set off to A\&E. It was suffocatingly hot, and it was going home time. Lancaster's traffic was gridlocked. $M$ sat paralyzed with fear in the passenger seat while I silently contemplated arriving at the RLI with him dead beside me.

As I raced down the hill to Dalton Square I could see it was hopeless. I swerved into the Square shouting, "Quick, run into the Surgery while I pay; I'll follow". No money! I grabbed a passing stranger, explained I'd accidentally poisoned my husband, and pleaded. She handed over the parking money, no questions asked - bless her!

I'd only just stuck the ticket on the window when $M$ came barrelling out clutching one of those sick bowls that look like party hats. Next stop A\&E. I forced the car into the gridlock, shouting "Quick! - Hospital! - he's drunk cleaning fluid". $M$ had remained silent throughout, but I was making an amazing amount of noise.

Arriving at the barrier of the RLI's visitors' car park I sent him running into $\mathrm{A} \& \mathrm{E}$. By now raindrops the size of $10 \mathrm{p}$ coins were plopping onto the hot tarmac and the sky was plum-coloured. I still had no parking money but who cared?

$M$ had been fast-tracked when I found him. Dr Natalie (I think) went off with the "Shout" bottle to look up how long he had to live and we stared sadly at the "party hat" bowl. Occasionally $M$ retched - for effect, in my opinion! Then those natural forces came into play and there was a deafening clap of thunder immediately overhead. A second later the fire alarms started to ring - and went on ringing.
The Hospital had been struck by lightning, specifically the fire alarm system of the Century Building although no one knew that for a while.

A\&E staff started the evacuation of the halt and the lame, the drunk, the hysterical (me), the silently traumatised $(M)$, the elderly on beds with their drip stands, the terrified Mum with her choking baby, the "hoodie" with blood pouring from his head, \&c. The crowd shuffled along uncomplaining towards the doors.

Outside the rain had become a monsoon. The glass canopy in front of $\mathrm{A} \& \mathrm{E}$ designed to protect ambulances and their injured human cargo from the elements was only just withstanding the hammering torrent. Water cascaded off the glass. There was nothing else for it but to cram ambulances, beds, drip stands, the ailing multitude plus their carers, porters, nurses, doctors, receptionists, cleaners and the rest under the glass canopy. It could have been very jolly but no one was in a fit state.

Half-an-hour passed, ambulances arrived, saw the scene and went elsewhere. Then word came that we could go back in. $M$ and I lost each other down two different corridors. When I caught up with him he was in the children's cubicle, with giant cartoon monkeys, tigers and snakes peeping at him from the walls. Natalie didn't think he would die, but he had to stay there under observation for six hours. He was hooked up to various monitoring devices, quite relaxed, and getting some satisfaction from telling everyone that I had tried to poison him.

After four hours he had to be moved to a ward - NHS rules. Off we went to Men's Medical for the remaining two hours, by which time it was past midnight. I wouldn't let him get on the bed because he wasn't ill, and it would have to be cleaned and re-made if he did, wouldn't it? Around 2 am we were discharged, exhausted, guilt-ridden (me), embarrassed (me), furious (him), and not on speaking terms.

Throughout the fire alarms kept up the skull-splitting racket, and later I discovered it had lasted ten hours. The calmness, good humour and stoicism of the staff that day were remarkable. Forgive me, all of you, for my crass stupidity that brought needless aggravation and used staff and resources pointlessly. I've been trying to make amends ever since.

Correspondence to: costermeyer@hotmail.com 